\title{
Mild Phenotype of Wolfram Syndrome Associated With a Common Pathogenic Variant Is Predicted by a Structural Model of Wolframin
}

Adi Wilf-Yarkoni, MD, MSc, Oded Shor, PhD, Avi Fellner, MD, Mark Andrew Hellmann, MD, Elon Pras, MD, Hagit Yonath, MD, Shiri Shkedi-Rafid, PhD, Lina Basel-Salmon, MD, PhD, Lili Bazak, PhD, Ruth Eliahou, MD, Lior Greenbaum, MD, PhD, Hadas Stiebel-Kalish, MD, Felix Benninger, MD, and Yael Goldberg, MD

Neurol Genet 2021;7:e578. doi:10.1212/NXG.0000000000000578

\section{Abstract}

\section{Objective}

To describe the WFS1 c.1672C>T; p.R558C missense variant, found in $1.34 \%$ of Ashkenazi Jews, that has a relatively mild phenotype and to use computational normal mode analysis (NMA) to explain the genotype-phenotype relationship.

\section{Methods}

The clinical, laboratory, and genetic features of 8 homozygotes were collected. A model of the wolframin protein was constructed, and NMA was used to simulate the effect of the variant on protein thermodynamics.

\section{Results}

Mean age at Wolfram syndrome (WS) diagnosis among homozygotes was 30 years; diabetes (7/8) was diagnosed at mean age 19 years (15-21 years), and bilateral optic atrophy (with MRI evidence of optic/chiasm atrophy) (6/8) at mean age 29 years (15-48 years). The oldest patient (62 years) also had gait difficulties, memory problems, parietal and cerebellar atrophy, and white matter hyperintense lesions. All retained functional vision with independent ambulation and self-care; none had diabetes insipidus or hearing loss. The p.R558C variant caused less impairment of protein entropy than WFS1 variants associated with a more severe phenotype.

\section{Conclusions}

The p.R558C variant causes a milder, late-onset phenotype of WS. We report a structural model of wolframin protein based on empirical functional studies and use NMA modeling to show a genotype-phenotype correlation across all homozygotes. Clinicians should be alert to this condition in patients with juvenile diabetes and patients of any age with a combination of diabetes and optic atrophy. Computational NMA has potential benefit for prediction of the genotype-phenotype relationship.

\author{
Correspondence \\ Dr. Goldberg \\ yaelgo43@gmail.com
}




\section{Glossary}

$\mathbf{E R}=$ endoplasmic reticulum; NMA $=$ normal mode analysis; $\mathbf{W S}=$ Wolfram syndrome.

Wolfram syndrome (WS) (OMIM 222300) is a rare inherited autosomal recessive neurodegenerative disease. ${ }^{1}$ It is characterized clinically by diabetes mellitus, bilateral optic atrophy, and deafness. ${ }^{1,2}$ Diabetes insipidus and anterior pituitary hypofunction have been described as well. ${ }^{3} \mathrm{Neu}-$ rologic complications, including bladder dysfunction, cerebellar ataxia, cognitive impairment, and psychiatric disturbances, tend to present later as the disease progresses. ${ }^{4,5}$ Classic brain MRI shows marked brainstem, cerebellum, and optic atrophy. ${ }^{6}$ Individuals with WS have a median lifespan of 30 years. ${ }^{7,8}$

WS is caused by a mutation in the WFS1 gene located on chromosome 4p16.1, consisting of 8 exons. WFS1 encodes the 890 -amino-acid-long wolframin protein that is thought to serve as a novel endoplasmic reticulum (ER) calcium channel or regulator of channel activity. ${ }^{9,10}$ The genotypephenotype correlation is complex. Biallelic pathogenic missense variants are less frequent and are associated with a significantly later age at diagnosis of both diabetes mellitus and optic atrophy than biallelic missense variants involving at least one truncating mutation. ${ }^{11,12}$ Significant phenotypic differences have been reported among the different missense variants. ${ }^{9,13}$ The WFS1 c.1672C $>$ T, p.R558C variant is reported in $1.34 \%$ of Ashkenazi Jews (see Web Resources: omim.org; ncbi.nih.gov/clinvar/variation/ 198835/; gnomad.broadinstitute.org/variant/4-6303194$\mathrm{C}-\mathrm{T}$ ? dataset=gnomad_r2_1). It was recently found to be associated with a milder phenotype. ${ }^{14}$

The aim of this study was to describe the unique late-onset phenotype caused by the p.R558C pathogenic variant and to use computational normal mode analysis (NMA) to simulate the effect of the missense mutation on the stability of the protein and predict the genotype-phenotype relationship.

\section{Methods}

\section{Standard Protocol Approvals, Registrations, and Patient Consents}

The study was approved by the Rabin Medical Center Institutional Review Board (Helsinki Committee 0187-19-RMC).

\section{Study Design and Data Collection}

A retrospective case series design was used. All patients enrolled in the study were homozygotes for the WFS1 variant NM 006005.3:c.1672C >T (p.Arg558Cys). Data were collected on family history, demographics, medical history, and medications. All patients underwent a neurologic/neuro-ophthalmologic evaluation including visual acuity, visual fields, color vision test, and dilated fundus examination, and brain MRI.

\section{Genetic Analysis}

Genetic analysis included whole-exome sequencing (patients 5 and 6), WFS1 gene sequencing (patients 1,3 , and 4), and targeted mutation analysis (patients 2,7 , and 8 ).

Data on the prevalence of the variant in the local population were retrieved from the local database of 636 exome trios.

\section{Wolframin Structure Prediction and NMS}

As the structure of wolframin is not available, we used the I-TASSER hierarchical protocol for automated protein structure prediction. ${ }^{15}$ We identified a cytosolic, transmembrane, and luminal domain, as previously published. ${ }^{16,17}$ The cytosolic domain (residues 1-310) and the luminal domain (residues 655-890) were modeled using the I-TASSER online server, ${ }^{15}$ and the transmembrane domain (residues 300-670) was modeled using the GPCR-I-TASSER online server. ${ }^{18}$ The resulting domains with overlapping residues were stitched together using the PyMol Molecular Graphics System, version 1.8 (Schrödinger, LLC, Cambridge, MA). To select the best fitting model, transmembrane structures with helices in opposite directions were chosen, and the minimal root mean square deviation between stitched structures was set at less than $2 \AA$. We eliminated all structures with coinciding residues in the z-plane for cytosolic and luminal residues with the transmembrane domain. The remaining 5 structures were combined to form a homotetramer model using the HSYMDOCK server. ${ }^{19}$ This produced 500 different structures that were screened for those most closely representing the properties of known calcium channels according to previous publications ${ }^{20,21}$ : pore diameter 4-6.3 $\AA$, smaller cytosolic than luminal pore size, and formation of a channel by the transmembrane domains with a maximal number of residues less than $20 \AA$ between any 2 facing subunits. These criteria were maximized to yield the modeled structure. Each in silico missense variant was created by mutagenesis plug-in using the PyMol system.

We compared the energetic effect of the p.Arg558Cys variant on wolframin and searched the literature for other cases of WS due to homozygous missense variants. ${ }^{9,13,22-25}$ The cases were divided into 2 groups according to the reported phenotype: classical phenotype and/or presentation of symptoms at a younger age (group 1) and milder disease affecting fewer organ systems and/or presenting at an older age (group 2). Elastic network contact model (ENCoM) coarse-grained NMA was used to evaluate the effect of the missense variants on the stability of the protein. This method is based on the ENCoM entropic considerations $\mathrm{C}$ package, ${ }^{26}$ available at the ENCoM development website (github.com/NRGlab/ENCoM), compiled on a Ubuntu platform (Canonical Group, London, UK). Using Matlab software (MathWorks, Natick, MA), for each variant, we subtracted the WT complex entropy from the missense variant 
Table 1 Characteristics of 8 Patients With WFS1 Variant c.1672C $>T^{\mathrm{a}}$

\begin{tabular}{|c|c|c|c|c|c|c|c|c|c|c|c|c|}
\hline Patient & $\begin{array}{l}\text { Age/ } \\
\text { sex }\end{array}$ & $\begin{array}{l}\text { Age } \\
\text { at } \\
\text { Dx }\end{array}$ & $\begin{array}{l}\text { DM } \\
\text { (age } \\
\text { at } \\
\text { onset) }\end{array}$ & $\begin{array}{l}\text { OA } \\
\text { (age } \\
\text { at } \\
\text { onset) }\end{array}$ & VA & VF & $\begin{array}{l}\text { Color } \\
\text { vision }\end{array}$ & $\begin{array}{l}\text { Cataract } \\
\text { (age at } \\
\text { onset) }\end{array}$ & $\begin{array}{l}\text { Neurologic } \\
\text { symptoms } \\
\text { (age at } \\
\text { examination) }\end{array}$ & $\begin{array}{l}\text { Brain MRI } \\
\text { (age at } \\
\text { imaging) }\end{array}$ & $\begin{array}{l}\text { Other } \\
\text { medical } \\
\text { conditions }\end{array}$ & $\begin{array}{l}\text { DM in } \\
\text { family } \\
\text { members }\end{array}$ \\
\hline 1 & $42 / F$ & 33 & $\begin{array}{l}\text { Yes } \\
(21)\end{array}$ & $\begin{array}{l}\text { Yes } \\
(33)\end{array}$ & $\begin{array}{l}R \\
6 / 8 \\
\text { L 6/ } \\
8.5\end{array}$ & $\begin{array}{l}\text { Bilateral } \\
\text { mild central } \\
\text { scotoma }\end{array}$ & $\begin{array}{l}\text { R 2.5/ } \\
12 \\
\text { L 0/12 }\end{array}$ & & None (42) & $\begin{array}{l}\text { Optic chiasm } \\
\text { and optic } \\
\text { nerve atrophy } \\
(42)\end{array}$ & & No \\
\hline 2 & $\begin{array}{l}62 / \\
M\end{array}$ & 32 & $\begin{array}{l}\text { Yes } \\
(18)\end{array}$ & $\begin{array}{l}\text { Yes } \\
(30)\end{array}$ & $\begin{array}{l}R \\
6 / \\
60 \\
\text { L 6/ } \\
30\end{array}$ & $\begin{array}{l}\text { Concentric } \\
\text { visual field } \\
\text { constriction }\end{array}$ & $0 / 12$ & & $\begin{array}{l}\text { Neurogenic } \\
\text { bladder, mild } \\
\text { cognitive } \\
\text { impairment, } \\
\text { and gait } \\
\text { instability (60) }\end{array}$ & $\begin{array}{l}\text { Optic chiasm, } \\
\text { optic nerve } \\
\text { atrophy, } \\
\text { cerebellar and } \\
\text { cerebral } \\
\text { atrophy, and } \\
\text { T2 } \\
\text { hyperintense } \\
\text { changes }(60)\end{array}$ & & No \\
\hline 3 & $41 / F$ & 31 & $\begin{array}{l}\text { Yes } \\
(18)\end{array}$ & $\begin{array}{l}\text { Yes } \\
\text { (33) }\end{array}$ & $\begin{array}{l}R \\
6 / \\
100 \\
\text { L 6/ } \\
40\end{array}$ & $\begin{array}{l}\text { Generalized } \\
\text { decreased } \\
\text { sensitivity }\end{array}$ & $0 / 12$ & & None (41) & $\begin{array}{l}\text { Optic chiasm } \\
\text { atrophy (31) }\end{array}$ & & $\begin{array}{l}\text { Adult } \\
\text { onset (F) }\end{array}$ \\
\hline 4 & $17 / F$ & 17 & $\begin{array}{l}\text { Yes } \\
(15)\end{array}$ & $\begin{array}{l}\text { Yes } \\
(15)\end{array}$ & $\begin{array}{l}R \\
6 / \\
10 \\
\text { L 6/ } \\
12\end{array}$ & & $0 / 12$ & & None (17) & $\begin{array}{l}\text { Optic nerve } \\
\text { atrophy (16) }\end{array}$ & $\begin{array}{l}\text { Osteoid } \\
\text { osteoma }\end{array}$ & $\begin{array}{l}\text { GDM + } \\
\text { adult- } \\
\text { onset (M) }\end{array}$ \\
\hline 5 & $30 / F$ & 30 & $\begin{array}{l}\text { Yes } \\
(20)\end{array}$ & No & & & & & None (30) & Normal (30) & & N/A \\
\hline 6 & $22 / F$ & 22 & No & $\begin{array}{l}\text { Yes } \\
(16)\end{array}$ & $\begin{array}{l}\mathrm{R} \\
6 / \\
12 \\
\mathrm{~L} 6 / \\
12\end{array}$ & & $0 / 12$ & & None (22) & $\begin{array}{l}\text { Optic nerve } \\
\text { atrophy (25) }\end{array}$ & & GDM (M) \\
\hline 7 & $27 / F$ & 27 & $\begin{array}{l}\text { Yes } \\
(21)\end{array}$ & No & & & & & None (27) & Not done & $\begin{array}{l}\text { Irregular } \\
\text { menses }\end{array}$ & GDM (M) \\
\hline 8 & $\begin{array}{l}53 / \\
M\end{array}$ & 53 & $\begin{array}{l}\text { Yes } \\
(20)\end{array}$ & $\begin{array}{l}\text { Yes } \\
(48)\end{array}$ & $\begin{array}{l}R \\
6 / 8 \\
L 6 / \\
10\end{array}$ & $\begin{array}{l}\text { Concentric } \\
\text { visual field } \\
\text { constriction }\end{array}$ & $0 / 12$ & Yes (25) & None (53) & $\begin{array}{l}\text { Optic chiasm } \\
\text { and optic } \\
\text { nerve atrophy } \\
\text { (53) }\end{array}$ & Seminoma & $\begin{array}{l}\text { GDM (2 } \\
\text { sisters) + } \\
\text { adult } \\
\text { onset (F) }\end{array}$ \\
\hline
\end{tabular}

Abbreviations: $\mathrm{DM}=$ diabetes mellitus; $\mathrm{Dx}=$ diagnosis; GDM = gestational diabetes; $\mathrm{MCl}=$ mild cognitive impairment; OA = optic atrophy; $\mathrm{VA}=$ visual acuity; $\mathrm{VF}=$ visual fields.

None of the patients had diabetes insipidus or deafness.

all patients were homozygotes for c.1672C $>\mathrm{T}$.

entropy and normalized the difference $(\Delta G)$ to the maximum absolute values. Cluster analysis was performed using MATLAB software, as described previously. ${ }^{26}$

We defined an interval $I \in\left[\operatorname{mean}(\Delta \mathrm{G})-0.5^{*} \operatorname{std}(\Delta \mathrm{G})\right.$, $\left.\operatorname{mean}(\Delta G)+0.5^{*} \operatorname{std}(\Delta G)\right]$ for each entropic $\Delta G$ profile. I.S $S_{1}$ was defined as the absolute mean of $\Delta G$ values belonging outside the interval; $I_{2} S_{2}$ was defined as the absolute mean of $\Delta \mathrm{G}$ values belonging inside the interval; and I. $S_{3}$ was defined as the ratio of std $(\Delta G) /$ mean $(\Delta G)$. The entropic profile of each variant compared with the WT contained information on total relative protein stability (mean $\Delta G$ ) and range of fluctuations of the energetic profile (std $\Delta \mathrm{G}$ ). In addition, we determined the most pronounced perturbation of $\Delta \mathrm{G}$ representing direct effects close to the location of the mutation $\left(S_{1}\right)$ and distant effects on $\Delta \mathrm{G}$ by the mutation $\left(\mathrm{S}_{2}\right) . \mathrm{S}_{3}$ represented the combined stability and fluctuability of the variant protein compared with the WT.

\section{Data Availability}

Anonymized data can be made available to qualified investigators on request to the corresponding author.

\section{Results}

\section{Demographic and Clinical Features}

The study group consisted of 8 patients, 6 women and 2 men, of mean age 37 years (range 17-62 years) (table 1 ). They included 8 homozygotes from 7 unrelated families ( 2 were sisters) of Ashkenazi Jewish origin. 
A

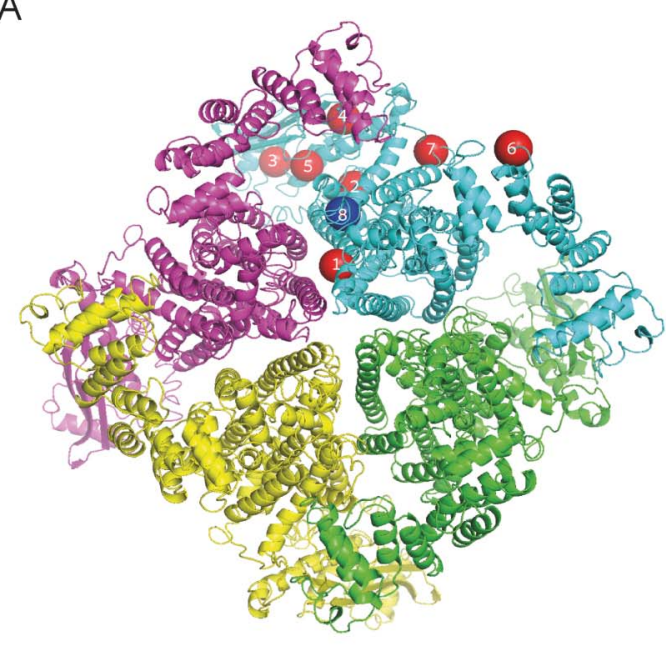

C

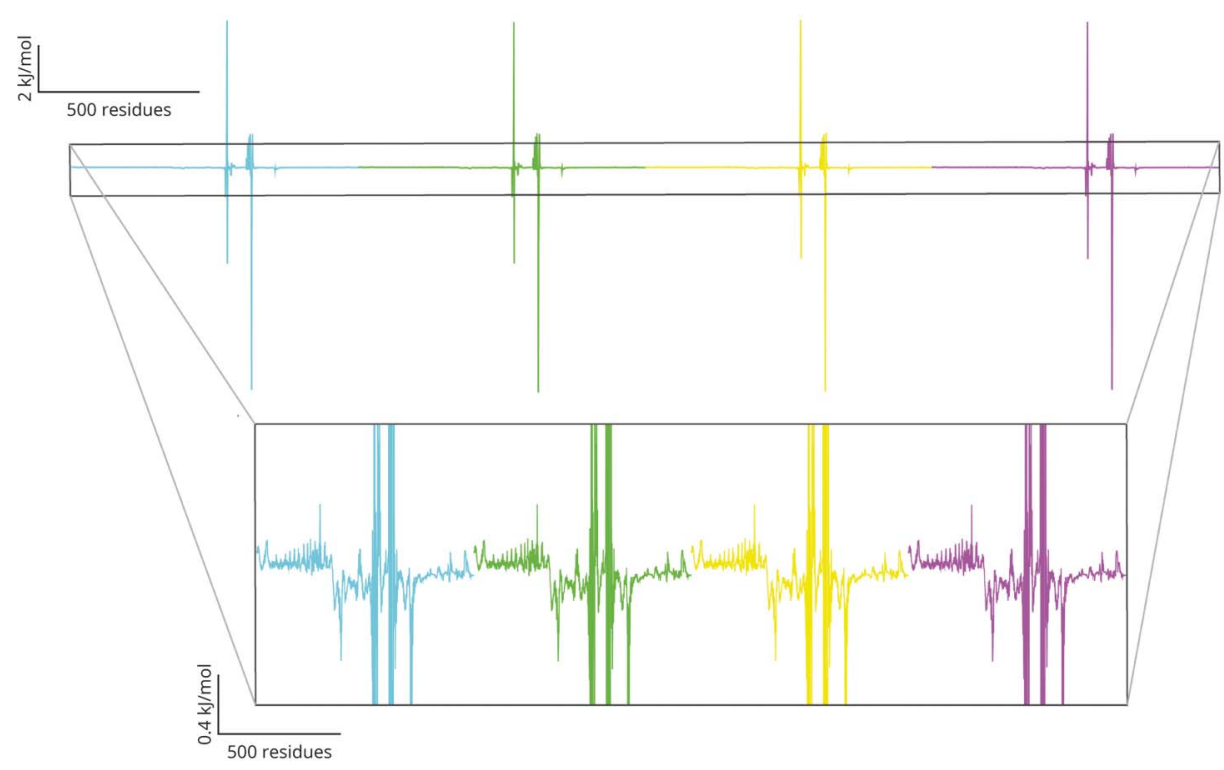

B

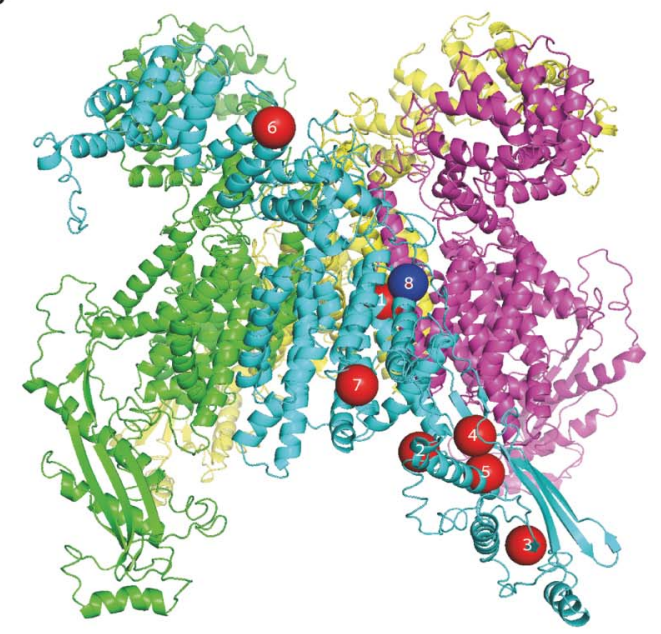

Cytoplasmatic (A) and lateral view (B). Known variants are indicated by red dots in each of the 4 subunits, and the unique variant reported here (c.1672C>T; p.R558C) is depicted in blue (no. 8). The known variants (red) are labeled in one of the subunits and are numbered from 1 to 7 for identification purposes according to table 2. Each subunit is color coded (blue, green, yellow, and magenta). The differences between the entropic profile based on normal mode analysis for the c.1672C>T; p.R558C variant to the entropic profile of the WT are shown for comparison (C). The y-scale is enlarged in the inlay for better visualization. Clear energy differences from WT are shown. The same color code as in schemes A and B is used to represent the subunit.

Mean age at genetic diagnosis of WS was 30.6 years (17-53 years). Insulin-dependent nonautoimmune diabetes mellitus was the first clinical feature in 7 patients (87.5\%). Diabetes was diagnosed in 7/8 homozygotes at mean age 19 years (range 15-21 years). Progressive bilateral optic atrophy was diagnosed in 6 patients at mean age 29 years (range 15-48 years), and cataract was diagnosed in 1 patient at age 25 years. All patients with optic atrophy had decreased visual acuity and reduced color vision. None of the patients in the cohort had sensorineural hearing loss or diabetes insipidus.

Other than optic atrophy, neurologic examination was normal in 9/10 patients. Patient 2, a 62-year-old man, had gait instability and complained of memory loss that had started at age 59 years.
Montreal Cognitive Assessment score indicated mild cognitive impairment mainly involving short-term memory.

Intrafamilial phenotypic heterogeneity was observed. Of the 2 sisters homozygous for the c.1672C>T variant, one (patient 6) had optic atrophy and no evidence of diabetes, and the other (patient 7) had diabetes and no evidence of optic atrophy.

The patients reported late-onset and/or gestational diabetes in 5 first-degree relatives of whom 4 were obligate carriers.

\section{Neuroradiologic Features}

Brain MRI studies were conducted in $7 / 8$ patients (table 1 ). Six (75\% of the cohort) showed evidence of optic nerve and/ 
Table 2 Cases of Wolfram Syndrome due to Homozygous Missense Variants Reported in the Literature WFS1 Variant

\begin{tabular}{|c|c|c|c|c|c|c|c|c|c|}
\hline & & $\begin{array}{l}\text { DM (age } \\
\text { at onset) }\end{array}$ & $\begin{array}{l}\text { OA (age } \\
\text { at onset) }\end{array}$ & $\begin{array}{l}\text { Deafness } \\
\text { (age at } \\
\text { onset) }\end{array}$ & $\begin{array}{l}\text { DI (age } \\
\text { at } \\
\text { onset) }\end{array}$ & $\begin{array}{l}\text { Neurologic } \\
\text { symptoms (age at } \\
\text { onset) }\end{array}$ & $\begin{array}{l}\text { Neurogenic } \\
\text { bladder (age at } \\
\text { onset) }\end{array}$ & $\begin{array}{l}\text { Location of } \\
\text { mutation }\end{array}$ & $\begin{array}{l}\text { Group by } \\
\text { severity }\end{array}$ \\
\hline 1 & $\begin{array}{l}\text { c.1885C>T } \\
\text { (Arg629Trp) } \\
13\end{array}$ & $\begin{array}{l}\text { Age not } \\
\text { reported }\end{array}$ & $\begin{array}{l}\text { Age not } \\
\text { reported }\end{array}$ & $\begin{array}{l}\text { Age not } \\
\text { reported }\end{array}$ & $\begin{array}{l}\text { Age not } \\
\text { reported }\end{array}$ & Age not reported & Age not reported & Transmembrane & 1 \\
\hline 2 & $\begin{array}{l}\text { C.1991T>C } \\
\left(\text { Leu664Arg) }{ }^{9}\right.\end{array}$ & 3 & 12 & 17 & & & & Luminal & 1 \\
\hline 3 & $\begin{array}{l}\text { c.2104G>A } \\
\text { (Gly702Ser) } \\
22\end{array}$ & & 10 & & & 27 & & Luminal & 1 \\
\hline 4 & $\begin{array}{l}\text { c.2411T>C } \\
\text { (Leu804Pro) }\end{array}$ & 5 & 9 & & & & & Luminal & 1 \\
\hline 5 & $\begin{array}{l}\text { c.2654C>T } \\
\text { (Ser885Leu) } \\
23\end{array}$ & 5 & 9 & 12 & & & & Luminal & 1 \\
\hline 6 & $\begin{array}{l}\text { c.472G>A } \\
\text { (Glu158Lys) }^{9}\end{array}$ & 27 & 19 & 39 & & & & Cytosol & 2 \\
\hline 7 & $\begin{array}{l}\text { c. } 1752 T>G \\
\text { (Tyr528Asp) } \\
25\end{array}$ & 9 & 24 & 24 & 25 & & & Transmembrane & 2 \\
\hline 8 & $\begin{array}{l}\text { c.1672C>T } \\
\text { (Arg558Cys) }\end{array}$ & 18 & 29 & & & & & Transmembrane & 2 \\
\hline
\end{tabular}

Abbreviations: $\mathrm{DI}=$ diabetes insipidus; $\mathrm{DM}=$ diabetes mellitus, $\mathrm{OA}=$ optic atrophy.

a Group 1-classical phenotype and/or presentation of symptoms at a younger age; group 2-milder disease affecting fewer organ systems and/or presenting at an older age.

or optic chiasm atrophy. All also had clinical evidence of optic atrophy. In the oldest patient in the cohort (patient 2, age 62 years), brain MRI also revealed cerebellar and cerebral atrophy mainly of the parietal lobes as well as T2-weighted signal intensity changes in the periventricular white matter and centrum semiovale areas.

\section{Prevalence}

The c.1672C $>\mathrm{T}$ variant was found in a monoallelic phase in 13 of $636(2.5 \%)$ exomes evaluated at the Genetic Institute of Rabin Medical Center. All carriers were of Ashkenazi Jewish origin. The prevalence of the variant among all Ashkenazi Jewish patients in our database was $13 / 350$ (3.7\%).

\section{Construction of Wolframin Functional Structure}

The spatial structure of the wolframin protein is unknown. Based on the assumption that wolframin behaves like a calcium channel protein, ${ }^{9,10}$ we constructed a homotetrameric model of the WT protein as described in Methods (figure 1, A and B and supplementary PDB, links.lww.com/NXG/A401).

\section{Energetic Profile of c.1672C $>T$ (p.R558C) Variant by NMA}

Our literature search yielded 8 homozygous missense WFS1 pathogenic variants (table 2) located in the cytosolic domain $\left[\right.$ c. $\left.472 \mathrm{G}>\mathrm{A}(\mathrm{Glu} 158 \mathrm{Lys})^{9}\right]$, transmembrane domain $[\mathrm{c} .1672 \mathrm{C}>\mathrm{T}$
(Arg558Cys), c.1752T $>\mathrm{G} \quad(\mathrm{Tyr} 528 \mathrm{Asp})^{25}$ and c.1885C $>\mathrm{T}$ $\left.(\text { Arg629Trp })^{13}\right]$, or luminal domain [c.2654C $>\mathrm{T}\left(\right.$ Ser885Leu), ${ }^{23}$ c.2411T>C (Leu804Pro), ${ }^{24}$ c.2104G $>\mathrm{A} \quad$ (Gly702Ser), ${ }^{22}$ and c.1991T>C (Leu664Arg) ${ }^{9}$ ] (figure 1). Using in silico mutagenesis, we studied the effect of each of these variants on protein thermodynamics using NMA and correlated the results to the clinical phenotype. The entropic difference $(\Delta G)$ between the WT WFS1 complex and the missense variant described here $(c .1672 \mathrm{C}>\mathrm{T}$; p.R558C) is shown in figure 1C.

To investigate the protein's energetic profile for each of the variant structures, we performed NMA and calculated the putative entropic changes $(\Delta G)$ by subtracting the WT entropic profile as described before. ${ }^{26}$ The mean $\Delta \mathrm{G}$ for each variant indicated the total energetic stability of the structure compared with the WT, whereas the SD indicated the range of fluctuations of the energetic profile. Of interest, analysis of the thermodynamic profile of 2 variants [c.1672C $>\mathrm{T}$ (Arg558Cys) and c.1752T $>\mathrm{G}$ (Tyr528Asp)] located in the transmembrane domain and associated with a milder clinical phenotype (table 2) resulted in negative values of mean $\Delta \mathrm{G}$. This implied that the protein was energetically more stable than the WT. To compare the thermodynamic profiles of the variants (represented by red dots in figure 1, $\mathrm{A}$ and $\mathrm{B}$ ), we combined the entropic profile scores (S1, S2, S3) of each variant. We found a clear separation of variants with a mild phenotype [c.472G $>$ A (Glu158Lys), c.1672C $>$ T 


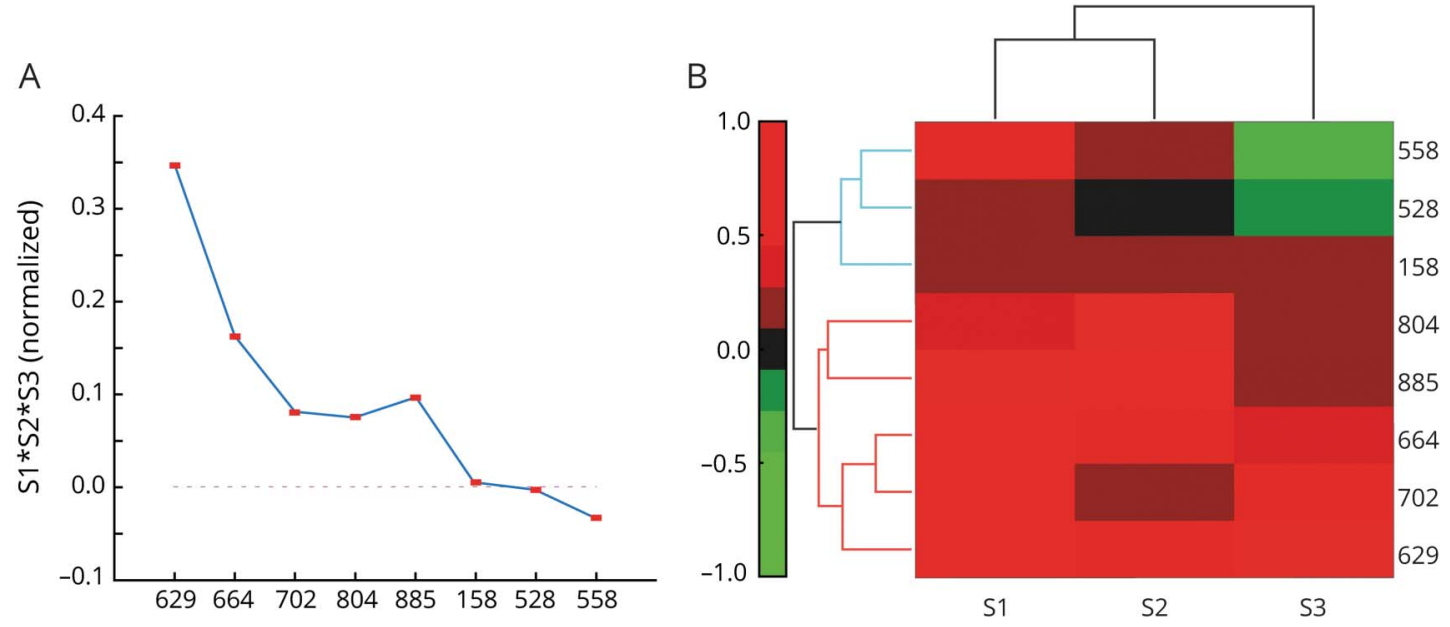

Combined normalized scores describing the entropy ( $\mathrm{S} 1 * \mathrm{~S} 2 * \mathrm{~S} 3)$ per variant. The differences in entropy scores are displayed for comparisons (A). Results of cluster analysis using a hierarchical clustering heatmap of the change in the normalized scores (S1, S2, and S3) for all variants (B). The vertical axis displays the individual variants analyzed (right). Color scale represents normalized z-scores.

(Arg558Cys), and c.1752T>G (Tyr528Asp)] and variants with a severe phenotype. The resulting characterization of all variants showed monotonically decreasing dependence of the combined scores as a function of phenotype and residue number (figure 2A). The segregation of the variants according to the thermodynamic scores is shown in the clustergram (figure $2 \mathrm{~B}$ ), with those associated with a mild phenotype clustered together, separate from those associated with a severe phenotype (table 2 ).

\section{Discussion}

We describe a unique relatively mild phenotype of WS in Ashkenazi Jews caused by the common c.1672C $>\mathrm{T}$ founder pathogenic variant. We constructed a structural model of wolframin based on empirical functional studies and used protein thermodynamics modeling with NMA to study the effect of the mutation on protein stability and predict variant-associated disease severity.

Our data provide evidence of the pathogenicity of this variant, designated "conflicting interpretations of pathogenicity" by ClinVar with referral to 6 submissions 4 were defined as pathogenic/ likely pathogenic and 2 as of uncertain significance. The reported frequency in Ashkenazi Jews is $1.72 \%$ in GnomAD genomes and $1.33 \%$ in GnomAD exomes (see Web Resources: omim.org; ncbi. nih.gov/clinvar/variation/198835/; gnomad.broadinstitute.org/ variant/4-6303194-C-T?dataset=gnomad_r2_1). The variant is rare in other ethnic groups, with an allele frequency of 0.000246 among Europeans. It has been reported a few times in the past. ${ }^{14,27-29}$ One homozygous patient had only juvenile diabetes and none of the other features typical of WS syndrome, ${ }^{27}$ and another was diagnosed with diabetes mellitus at age 33 years and with optic atrophy at age 53 years. ${ }^{29}$ Bansal et al. ${ }^{14}$ reported on 8 homozygotes in a cohort of 475 individuals diagnosed with type 1 diabetes at a relatively late age (mean $17.8 \pm 8.3$ years) with low penetrance of optic atrophy. This variant was also observed in compound heterozygous combination with other variants in several individuals with WS. ${ }^{28}$

Most homozygotes in our cohort presented with slowly progressive bilateral optic atrophy. Thus, although they retained functional vision enabling independent ambulation and self-care, the penetrance of optic atrophy was high, in contrast to the report of Bansal et al. ${ }^{14}$ In one of our patients, neurologic complications of WS developed at the age of 59 years suggesting that other features of WS might also evolve at a later age.

Diabetes mellitus was the first and the most common presentation in our cohort, although mean age at its diagnosis was higher than expected in WS. There have been reports of dominant inheritance of WS. ${ }^{30}$ Although none of the heterozygote family members of our cohort reported features of WS, 5 of them had adult-onset or gestational diabetes. This is in line with a previous study by Bansal et al., ${ }^{27}$ in which analysis of sequence and genotype data in 2 case-controlled cohorts of Ashkenazi ancestry, demonstrated an association of this variant with an increased risk of type 2 diabetes in heterozygotes (odds ratio $1.81, p=0.004$ ). Single gene mutations that affect beta-cell function account for $1-2 \%$ of all cases of diabetes. However, phenotypic heterogeneity and lack of family history of diabetes mellitus can limit the diagnosis of monogenic forms of diabetes. Identification of WS in individuals diagnosed with diabetes in childhood or adolescence is important because the management and prognosis of WS differs from type 1 diabetes. ${ }^{31}$ Suspicions should also be raised in the presence of a finding of islet-cell autoantibodies that are positive in $10-20 \%$ of patients with WS. ${ }^{32}$ Early diagnosis of WS may improve an individual's prognosis, potential treatment or referral to clinical trials, and 
detection of WS-related complications, and hasten genetic counseling of family members.

Previous empirical studies implied that WFS1 functions as a $\mathrm{Ca}^{2+}$ ion channel. ${ }^{20,21}$ We present a structural model based on empirical and functional studies of WFS1. Following the selection of one of the homotetrameric structures best representing known $\mathrm{Ca}^{2+}$ - channel properties, NMA modeling provided excellent genotype-phenotype correlation across all homozygous variants. The agreement of the modeled thermodynamic fluctuations with the clinical consequences of the variants suggests that our structural model is close to the still unresolved structure of WFS1. Moreover, NMA and thermodynamic fluctuations correlate with functional data and are strong indicators of phenotype-genotype correlations. ${ }^{26}$ The computational analysis of the thermodynamic profile of the variants revealed a locationbased separation. Variants located in the transmembrane domain seemed to be energetically more stable than the WT except those situated in the ion channel pore possibly explaining the severe phenotype seen in the c.1885C variant. This finding supports previous published evidence of more pronounced functional effects of mutations located outside the transmembrane domain. ${ }^{16}$ In addition, a clear entropy-based distinction was seen between variants associated with a milder phenotype, which were clustered together and separated from variants with a more severe phenotype.

We have shown the unique thermodynamic profile caused by the p.R558C variant. As ER stress has been suggested to be involved in the pathogenesis of $\mathrm{WS},{ }^{33}$ it seems reasonable to assume that among homozygous for this variant, regulation of the unfolded protein response pathway, and consequently on ER stress, is mildly disturbed. However, further studies are needed to correlate between the various thermodynamic profiles, their effect on the pathogenic mechanisms leading to WS, and their effect of the on the extent of ER stress. This might also help design a mutation-based therapeutic strategy for patients with WS.

Carrier screening is recommended for many recessive diseases, particularly in Ashkenazi Jews. ${ }^{34}$ The p.R558C WS variant has an estimated carrier frequency of $1 / 36$ in this population. Although homozygotes have a milder form of WS, it is still associated with significant morbidity. Therefore, adding this variant to carrier screening panels might be considered.

In conclusion, WFS1 p.R558C is a very common pathogenic variant among Ashkenazi Jews. It is associated with a milder phenotype but high morbidity. Protein modeling and thermodynamic NMA suggest a structural mechanism that may explain the milder phenotype. Our findings provide proof of concept for the use of mutated protein structural modeling and energetic analysis to predict phenotype severity in yet undiscovered pathogenic variants of WS. Clinicians should be alert to this variant among young Ashkenazi Jewish patients with early-onset diabetes, even if positive for autoimmune antibodies, and in adults with diabetes mellitus and optic atrophy.

\section{Acknowledgment}

The authors acknowledge Gloria Ganzach for the English editing.

\section{Study Funding}

No targeted funding reported.

\section{Disclosure}

The authors report no disclosures relevant to the manuscript. Go to Neurology.org/NG for full disclosures.

\section{Publication History}

Received by Neurology: Genetics December 22, 2020. Accepted in final form January 27, 2021.

\section{Appendix Authors}

\begin{tabular}{lll}
\hline Name & Location & Contribution \\
\hline $\begin{array}{l}\text { Adi Wilf- } \\
\text { Yarkoni, MD, } \\
\text { MSc }\end{array}$ & $\begin{array}{l}\text { Rabin Medical Center, } \\
\text { Petach Tikva, Israel }\end{array}$ & $\begin{array}{l}\text { Analysis or interpretation of } \\
\text { the data and drafting or } \\
\text { revising the manuscript for } \\
\text { intellectual content }\end{array}$ \\
$\begin{array}{lll}\text { Oded Shor, } \\
\text { PhD }\end{array}$ & $\begin{array}{l}\text { Rabin Medical Center, } \\
\text { Petach Tikva, Israel }\end{array}$ & $\begin{array}{l}\text { Analysis or interpretation of } \\
\text { the data and drafting or } \\
\text { revising the manuscript for } \\
\text { intellectual content }\end{array}$ \\
\hline
\end{tabular}

\begin{tabular}{lll}
\hline Avi Fellner, & Rabin Medical Center, & $\begin{array}{l}\text { Interpretation of the data and } \\
\text { revising the manuscript for } \\
\text { intellectual content }\end{array}$
\end{tabular}

\begin{tabular}{lll}
\hline $\begin{array}{l}\text { Mark A. } \\
\text { Hellmann, } \\
\text { MD }\end{array}$ & $\begin{array}{l}\text { Rabin Medical Center, } \\
\text { Petach Tikva, Israel }\end{array}$ & $\begin{array}{l}\text { Revising the manuscript for } \\
\text { intellectual content }\end{array}$ \\
\hline $\begin{array}{l}\text { Elon Pras, } \\
\text { MD }\end{array}$ & $\begin{array}{l}\text { Sheba Medical Center, } \\
\text { Tel Hashomer, Israel }\end{array}$ & $\begin{array}{l}\text { Major role in acquisition of the } \\
\text { data }\end{array}$ \\
\hline $\begin{array}{l}\text { Hagit } \\
\text { Yonath, MD }\end{array}$ & $\begin{array}{l}\text { Sheba Medical Center, } \\
\text { Tel Hashomer, Israel }\end{array}$ & $\begin{array}{l}\text { Major role in acquisition of the } \\
\text { data }\end{array}$ \\
$\begin{array}{l}\text { Shiri Shkedi- } \\
\text { Rafid, PhD }\end{array}$ & $\begin{array}{l}\text { Hadassah-Hebrew } \\
\text { University Hospital, } \\
\text { Jerusalem, Israel }\end{array}$ & $\begin{array}{l}\text { Major role in acquisition of the } \\
\text { data }\end{array}$ \\
\hline
\end{tabular}

\begin{tabular}{lll}
\hline $\begin{array}{l}\text { Lina Basel- } \\
\text { Salmon, MD, } \\
\text { PhD }\end{array}$ & $\begin{array}{l}\text { Rabin Medical Center, } \\
\text { Petach Tikva, Israel }\end{array}$ & $\begin{array}{l}\text { Interpretation of the data and } \\
\text { revising the manuscript for } \\
\text { intellectual content }\end{array}$ \\
\hline $\begin{array}{l}\text { Lili Bazak, } \\
\text { PhD }\end{array}$ & $\begin{array}{l}\text { Rabin Medical Center, } \\
\text { Petach Tiqva, Israel }\end{array}$ & Interpretation of the data \\
\hline $\begin{array}{l}\text { Ruth } \\
\text { Eliahou, MD }\end{array}$ & $\begin{array}{l}\text { Rabin Medical Center, } \\
\text { Petach Tikva, Israel }\end{array}$ & $\begin{array}{l}\text { Revising the manuscript for } \\
\text { intellectual content }\end{array}$ \\
\hline $\begin{array}{l}\text { Lior } \\
\text { Greenbaum, } \\
\text { MD, PhD }\end{array}$ & $\begin{array}{l}\text { Sheba Medical Center, } \\
\text { Tel Hashomer, Israel }\end{array}$ & $\begin{array}{l}\text { Major role in acquisition of the } \\
\text { data }\end{array}$ \\
$\begin{array}{l}\text { Hadas } \\
\text { Stiebel- } \\
\text { Kalish, MD }\end{array}$ & $\begin{array}{l}\text { Rabin Medical Center, } \\
\text { Petach Tikva, Israel }\end{array}$ & $\begin{array}{l}\text { Major role in acquisition of the } \\
\text { data and revising the } \\
\text { manuscript for intellectual } \\
\text { content }\end{array}$ \\
$\begin{array}{l}\text { Felix } \\
\text { Benninger, } \\
\text { MD }\end{array}$ & $\begin{array}{ll}\text { Rabin Medical Center, } \\
\text { Petach Tikva, Israel }\end{array}$ & $\begin{array}{l}\text { Analysis or interpretation of } \\
\text { the data and drafting or } \\
\text { revising the manuscript for } \\
\text { intellectual content }\end{array}$ \\
& &
\end{tabular}


Appendix (continued)

\begin{tabular}{lll}
\hline Name & Location & Contribution \\
\hline $\begin{array}{l}\text { Yael } \\
\text { Goldberg, }\end{array}$ & Rabin Medical Center, \\
MD & Petach Tikva, Israel & $\begin{array}{l}\text { Major role in acquisition of } \\
\text { the data, analysis or } \\
\text { interpretation of the data, } \\
\text { and drafting or revising the } \\
\text { manuscript for intellectual } \\
\text { content }\end{array}$ \\
\end{tabular}

\section{References}

1. Wolfram DJ, Wagener HP. Diabetes mellitus and simple optic atrophy among siblings: report of four cases. Mayo Clin Proc 1938;13:715-718.

2. Barrett TG, Bundey SE, Macleod AF. Neurodegeneration and diabetes: UK nationwide study of Wolfram (DIDMOAD) syndrome. Lancet (London, England) 1995; 346:1458-1463.

3. Rigoli L, Bramanti P, Di Bella C, De Luca F. Genetic and clinical aspects of Wolfram syndrome 1, a severe neurodegenerative disease. Pediatr Res 2018;83:921-929.

4. Bischoff AN, Reiersen AM, Buttlaire A, et al. Selective cognitive and psychiatric manifestations in Wolfram syndrome. Orphanet J Rare Dis 2015;10:66.

5. Leiva-Santana C, Carro-Martinez A, Monge-Argiles A, Palao-Sanchez A. Neurologic manifestations in Wolfram's syndrome [in French]. Revue Neurologique 1993;149:26-29.

6. Gocmen R, Guler E. Teaching NeuroImages: MRI of brain findings of Wolfram (DIDMOAD) syndrome. Neurology 2014;83:e213-214.

7. Barrett TG, Bundey SE. Wolfram (DIDMOAD) syndrome. J Med Genet 1997;34: $838-841$.

8. Kinsley BT, Swift M, Dumont RH, Swift RG. Morbidity and mortality in the Wolfram syndrome. Diabetes Care 1995;18:1566-1570.

9. Gasparin MRR, Crispim F, Paula SL, et al. Identification of novel mutations of the WFS1 gene in Brazilian patients with Wolfram syndrome. Eur J Endocrinol 2009;160:309-316.

10. Sütt S, Altpere A, Reimets R, et al. Wfs1-deficient animals have brain-region-specific changes of $\mathrm{Na}+, \mathrm{K}+-\mathrm{ATPase}$ activity and mRNA expression of $\alpha 1$ and $\beta 1$ subunits. J Neurosci Res 2015;93:530-537.

11. Astuti D, Sabir A, Fulton P, et al. Monogenic diabetes syndromes: locus-specific databases for Alström, Wolfram, and Thiamine-responsive megaloblastic anemia Hum Mutat 2017;38:764-777.

12. Chaussenot A, Bannwarth S, Rouzier C, et al. Neurologic features and genotypephenotype correlation in Wolfram syndrome. Ann Neurol 2011;69:501-508.

13. Kadayifci A, Kepekci Y, Coskun Y, Huang Y. Wolfram syndrome in a family with variable expression. Acta Med (Hradec Kralove) 2001;44:115-118.

14. Bansal V, Boehm BO, Darvasi A. Identification of a missense variant in the WFS1 gene that causes a mild form of Wolfram syndrome and is associated with risk for type 2 diabetes in Ashkenazi Jewish individuals. Diabetologia 2018;61:2180-2188.

15. Yang J, Zhang Y. Protein structure and function prediction using I-TASSER. Curr Protoc Bioinformatics 2015;52:2.

16. Qian X, Qin L, Xing G, Cao X. Phenotype prediction of pathogenic nonsynonymous single nucleotide polymorphisms in WFS1. Scientific Rep 2015;5:14731.
17. Strom TM, Hörtnagel K, Hofmann S, et al. Diabetes insipidus, diabetes mellitus, optic atrophy and deafness (DIDMOAD) caused by mutations in a novel gene (wolframin) coding for a predicted transmembrane protein. Hum Mol Genet 1998;7:2021-2028.

18. Zhang J, Yang J, Jang R, Zhang Y. GPCR-I-TASSER: a hybrid approach to G proteincoupled receptor structure modeling and the application to the human genome. Structure (London, England: 1993) 2015;23:1538-1549.

19. Yan Y, Tao H, Huang SY. HSYMDOCK: a docking web server for predicting the structure of protein homo-oligomers with $\mathrm{Cn}$ or Dn symmetry. Nucleic Acids Res 2018;46:W423-w431.

20. Hofmann S, Philbrook C, Gerbitz KD, Bauer MF. Wolfram syndrome: structural and functional analyses of mutant and wild-type wolframin, the WFS1 gene product. Hum Mol Genet 2003;12:2003-2012.

21. Osman AA, Saito M, Makepeace C, Permutt MA, Schlesinger P, Mueckler M. Wolframin expression induces novel ion channel activity in endoplasmic reticulum membranes and increases intracellular calcium. J Biol Chem 2003;278: 52755-52762.

22. Chaussenot $\mathrm{A}$, Rouzier $\mathrm{C}$, Quere $\mathrm{M}$, et al. Mutation update and uncommon phenotypes in a French cohort of 96 patients with WFS1-related disorders. Clin Genet 2015;87:430-439.

23. Hardy C, Khanim F, Torres R, et al. Clinical and molecular genetic analysis of 19 Wolfram syndrome kindreds demonstrating a wide spectrum of mutations in WFS1. Am J Hum Genet 1999;65:1279-1290.

24. $\mathrm{Xu} \mathrm{Q}, \mathrm{Qu} \mathrm{H}$, Wei S. Clinical and molecular genetic analysis of a new mutation in children with Wolfram syndrome: a case report. Mol Med Rep 2013;7:965-968.

25. Zalloua PA, Azar ST, Delépine M, et al. WFS1 mutations are frequent monogenic causes of juvenile-onset diabetes mellitus in Lebanon. Hum Mol Genet 2008;17: 4012-4021.

26. Helbig I, Lopez-Hernandez T, Shor O, et al. A recurrent missense variant in AP2Ml impairs clathrin-mediated endocytosis and causes developmental and epileptic encephalopathy. Am J Hum Genet 2019;104:1060-1072.

27. Bansal V, Gassenhuber J, Phillips T, et al. Spectrum of mutations in monogenic diabetes genes identified from high-throughput DNA sequencing of 6888 individuals. BMC Med 2017;15:213.

28. Cano A, Rouzier C, Monnot S, et al. Identification of novel mutations in WFS1 and genotype-phenotype correlation in Wolfram syndrome. Am J Med Genet A 2007; 143a:1605-1612.

29. Lieber DS, Vafai SB, Horton LC, et al. Atypical case of Wolfram syndrome revealed through targeted exome sequencing in a patient with suspected mitochondrial disease. BMC Med Genet 2012;13:3.

30. De Franco E, Flanagan SE, Yagi T, et al. Dominant ER stress-inducing WFS1 mutations underlie a genetic syndrome of neonatal/infancy-onset diabetes, congenital sensorineural deafness, and congenital cataracts. Diabetes 2017;66:2044-2053.

31. Blanco-Aguirre ME, la Parra DR, Tapia-Garcia H, et al. Identification of unsuspected Wolfram syndrome cases through clinical assessment and WFS1 gene screening in type 1 diabetes mellitus patients. Gene 2015;566:63-67.

32. Rohayem J, Ehlers C, Wiedemann B, et al. Diabetes and neurodegeneration in Wolfram syndrome: a multicenter study of phenotype and genotype. Diabetes care 2011;34:1503-1510.

33. Pallotta MT, Tascini G, Crispoldi R, et al. Wolfram syndrome, a rare neurodegenerative disease: from pathogenesis to future treatment perspectives. J Transl Med 2019; 17:238.

34. Gross SJ, Pletcher BA, Monaghan KG. Carrier screening in individuals of Ashkenazi Jewish descent. Genet Med 2008;10:54-56. 


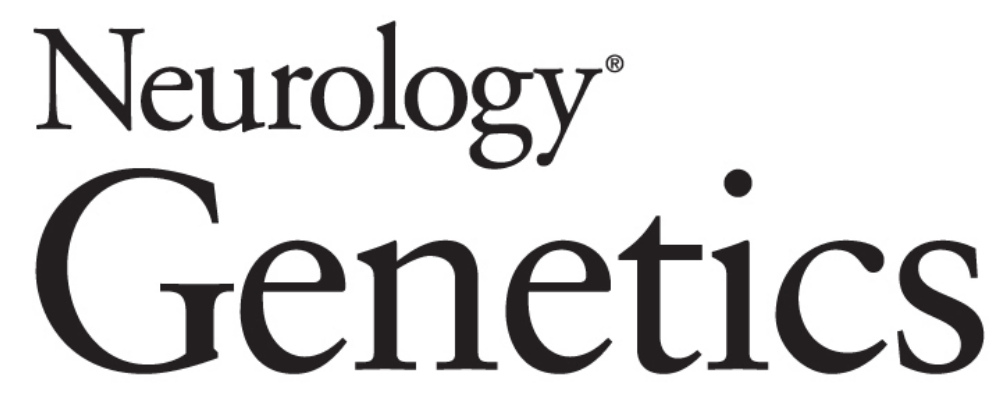
Mild Phenotype of Wolfram Syndrome Associated With a Common Pathogenic Variant Is Predicted by a Structural Model of Wolframin
Adi Wilf-Yarkoni, Oded Shor, Avi Fellner, et al.
Neurol Genet 2021;7;
DOI 10.1212/NXG.0000000000000578

This information is current as of March 19, 2021

\begin{abstract}
Updated Information \&
Services

including high resolution figures, can be found at:

http://ng.neurology.org/content/7/2/e578.full.html

References

This article cites 34 articles, 6 of which you can access for free at: http://ng.neurology.org/content/7/2/e578.full.html\#\#ref-list-1

Citations

This article has been cited by 2 HighWire-hosted articles: http://ng.neurology.org/content/7/2/e578.full.html\#\#otherarticles

Permissions \& Licensing its entirety can be found online at:

http://ng.neurology.org/misc/about.xhtml\#permissions

Reprints

Information about ordering reprints can be found online: http://ng.neurology.org/misc/addir.xhtml\#reprintsus
\end{abstract} Information about reproducing this article in parts (figures,tables) or in

Neurol Genet is an official journal of the American Academy of Neurology. Published since April 2015, it is an open-access, online-only, continuous publication journal. Copyright Copyright $\odot 2021$ The Author(s). Published by Wolters Kluwer Health, Inc. on behalf of the American Academy of Neurology.. All rights reserved. Online ISSN: 2376-7839.

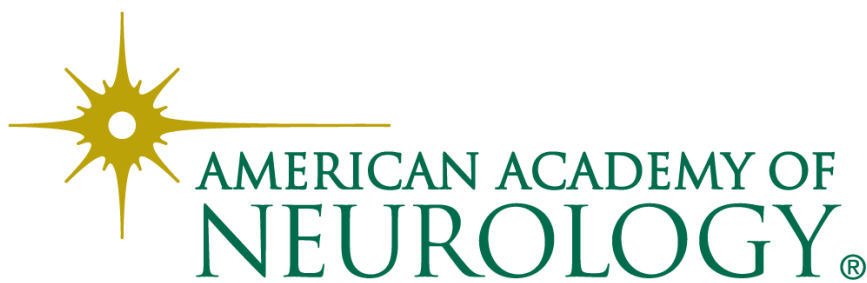

